\title{
Pendampingan Gerakan Literasi Pendidikan Kesetaraan Melalui Papan Edukasi Berbasis Karakter di PKBM Nurain, Kabupaten Bone Bolango
}

\author{
Haris Danial ${ }^{1}$, Zulva Rosari Usman ${ }^{2}$ \\ 1, 2, Universitas Negeri Gorontalo \\ 1'harisdanial@ung.ac.id; 2zulvarosariusman@gmail.com
}

\begin{abstract}
Abstrak
Program pengabdian masyarakat ini merupakan salah satu program yang dilakukan oleh tim pengusul untuk mendampingi gerakan literasi pendidikan kesetaraan melalui papan edukasi berbasis karakter di PKBM Nurain Kabupaten Bone Bolango. Tujuan penyelenggaraan program pengabdian ini adalah 1) Meningkatkan motivasi belajar peserta didik pendidikan kesetaraan pada mata pelajaran Bahasa Inggris; 2) Mengaktifkan peserta didik dalam belajar Bahasa Inggris tanpa membebani faktor gradasi usia dalam belajar; 3) Meningkatkan kompetensi Bahasa Inggris peserta didik di dalam kelas, dan 4) Menunjang proses pembelajaran Bahasa Inggris di dalam kelas. Pelaksanaan kegiatan pengabdian mandiri di PKBM Nurain, Desa Dunggala Kabupaten Bone Bolango ini lebih ditekankan pada tujuan untuk meningkatkan motivasi belajar peserta didik pendidikan kesetaraan di PKBM Nurain. Melalui program ini baik dosen dapat mengaplikasikan pengetahuan, ilmu dan keterampilan maupun teknologi untuk menangani kekurangan dan permasalahan yang dihadapi peserta didik di PKBM Nurain Desa Dunggala.
\end{abstract}

Kata Kunci: gerakan literasi, papan edukasi berbasis karakter, kesetaraan

\section{Pendahuluan}

Karakter merupakan bagian integral yang harus dibangun agar generasi muda memiliki sikap dan pola pikir yang berlandaskan moral yang kokoh dan benar. Hal ini senada dengan apa yang dikemukakan oleh Widyahening \& Wardhani (2016) bahwa pendidikan karakter memiliki peranan penting terhadap kehidupan manusia, khususnya dalam melindungi diri sendiri, membentuk kepribadian seseorang berdasarkan kepercayaan diri setiap individu, dan bahkan memiliki perilaku yang baik untuk saling menghargai terhadap perbedaan.

Pendapat yang sama juga datang dari Diggs \& Akos (2016) dan Nurhasanah \& Nida (2016) bahwa pendidikan karakter memiliki hubungan yang positif antara kesuksesan akademik untuk membentuk persepsi sosial yang positif. Dalam kaitannya, untuk membangun karakter setiap generasi muda, peranan seorang guru atau tutor dituntut untuk mampu bersikap profesional dalam membangun karakter anak didik sehingga menjadi bangsa Indonesia yang berkarakter baik. Akan tetapi, untuk mewujudkan pribadi yang berkualitas dan terampil, seorang guru harus bisa menciptakan suasana pembelajaran yang kondusif sehingga peserta didik aktif dan parstisipatif di dalam kelas. Salah satu hal yang menjadi tantangan tersendiri bagi guru atau tutor adalah motivasi https://madaniya.pustaka.my.id/journals/contents/article/view/83 
peserta didik yang menurun dalam belajar yang pada akhirnya berimbas pada kesulitan mereka untuk memahami setiap materi yang diajarkan.

Lembaga pendidikan non formal kesetaraan paket $A, B$, dan $C$ merupakan salah satu lembaga pendidikan yang disediakan bagi warga belajar putus sekolah yang ingin melanjutkan pendidikannya, yang bertujuan untuk mengecam pendidikan yang setara dengan pendidikan formal. Potret pendidikan non formal seperti ini memiliki konsep yang berbeda dengan pendidikan formal pada umumnya. Hal ini terlihat dari beberapa aspek, antara lain: 1) alokasi waktu pembelajaran yang disediakan di dunia pendidikan formal berbeda dengan pendidikan informal kesetaraan, 2) usia peserta didik pada pendidikan informal tidak homogen dan tidak dibatasi pada usia tertentu, dan 3) jenis pekerjaan menjadi salah satu faktor untuk menentukan tingkat keaktifan dan kehadiran di dalam kelas. Dalam hal ini, pekerjaan mempengaruhi cara peserta didik belajar di dalam kelas.

Bentuk pembelajaran non formal di atas biasanya ditemukan pada Pusat Kegiatan Belajar Masyarakat (PKBM) yang pada umumnya mengarah pada pembelajaran kesetaraan. Oleh karena itu, strategi dan cara pembelajaran di dalam kelas harus benarbenar disiapkan dengan matang, termasuk mempersiapkan media yang dapat membangkitkan motivasi warga dalam belajar. Hal ini harus selaras dengan kemampuan daya tangkap peserta didik dalam memahami materi yang diajarkan. Terlebih lagi, faktor usia dan pekerjaan menjadi dua faktor tertentu yang perlu dipertimbangkan oleh tutor dalam mengajar di dalam kelas.

Pengabdian ini mengarah pada kegiatan pembelajaran Bahasa Inggris dengan menggunakan media pembelajaran papan edukasi. Banyak penelitian terdahulu yang telah menerapkan papan edukasi dalam proses pembelajaran bagi usia heterogen. Seperti halnya, Prameswara \& Siswanto (2016:424) menjelaskan bahwa permainan papan atau board game dapat memicu setiap pemain dapat langsung berinteraksi dengan karakter dan permainan serta pemain lain sehingga ada interaksi yang memuat permainan menjadi lebih spontan dan dinamis. Penelitian yang sama juga dilakukan oleh Simbolon, Parlindungan, \& Sibuea (2018:12) dalam konsep permainan papan edukasi yang diterapkan bagi siswa SMA Negeri 1 Padangsidimpuan dalam mata pelajaran bahasa inggris. Hasil temuan ini menunjukkan bahwa melalui penerapan permainan papan edukasi, itu dapat meningkatkan rasa ingin tahu dan kreativitas siswa. Peserta didik dapat bergiliran membuat kalimat masing-masing di sekitar kelompok, atau dapat saling memanggil. Dengan demikian, penelitian-penelitian ini dapat merumuskan bahwa papan edukasi mampu menstimulus karakter dan kemampuan siswa dalam proses pembelajaran.

Berdasarkan uraian di atas, penulis melakukan pengabdian pada pendidikan kesetaraan Paket C di PKBM Nurain, Kabupaten Bone Bolango dengan mempertimbangkan kondisi kelas yang jauh berbeda atmosfernya dengan lingkungan pendidikan formal pada umumnya. Sebagaimana yang telah dijelaskan dalam Permendikbud Nomor 81 Tahun 2013 tentang Pendirian Satuan Pendidikan Non Formal bahwa program pendidikan nonformal adalah layanan pendidikan yang diselenggarakan untuk memberdayakan masyarakat melalui pendidikan kecakapan hidup, pendidikan keaksaraan, pendidikan keterampilan dan pelatihan kerja, pendidikan kesetaraan, serta pendidikan lain yang ditujukan untuk mengembangkan kemampuan peserta didik. Oleh 
karena itu, usia bagi peserta didik yang mengikuti pendidikan kesetaraan bersifat heterogen. Dalam arti, konsep pendidikan kesetaraan berbeda dengan pendidikan formal yang justru jenjang usia lebih diperhatikan pada angka yang homogen.

Berdasarkan hasil wawancara yang dilakukan dengan tutor bahasa Inggris dan pengelola PKBM Nurain, beberapa hal yang menjadi kendala bagi setiap tutor dalam mengajarkan peserta didik di dalam kelas, antara lain:

1) Peserta didik seringkali memetakan diri dalam lingkungan pembelajaran yang heterogen. Konsep ini muncul karena adanya sikap tidak berani dan malu bagi setiap peserta didik yang usia lanjut, yang tidak berani menjawab atau merespon pertanyaan tutor.

2) Faktor usia yang berjenjang dari $18-60$ tahun menjadi salah satu ketakutan tersendiri baik dari usia muda maupun usia lanjut untuk berinteraksi di dalam kelas

3) Kompetensi yang tidak seimbang menjadi alasan bagi setiap peserta didik untuk tidak percaya diri dalam merespon apa yang ditanyakan oleh guru

4) Motivasi belajar masih kurang karena kebanyakan peserta didik berdalih dengan pekerjaan yang membebani mereka untuk akhirnya kesempatan belajar sudah tidak ada lagi.

Untuk itu, dengan memperhatikan kondisi pendidikan kesetaraan yang terpaut oleh usia heterogen, penulis berupaya untuk merancang konsep pengabdian dengan menghadirkan meduia papan edukasi yang diharapkan mampu membangkitkan motivasi belajar bagi peserta didik. Media ini diharapkan dapat menjembatani benang merah penghubung antara faktor usia dan pekerjaan yang menjadi masalah tutor dalam pengajaran Bahasa Inggris di dalam kelas. Dalam kegiatannya, media ini diharapkan dapat mencipatakan suasana yang menyenangkan dan berbobot. Berbobot yang dimaksud adalah menggali potensi diri peserta didik dengan membawa mereka ke ranah kreativitas, sehingga mereka aktif dan bisa menciptakan suasana kelas tidak jenuh.

Khususnya dalam pembelajaran Bahasa Inggris, papan edukasi berbasis karakter diharapkan dapat menuntun keaktifan peserta didik di dalam kelas. Media ini diharapkan menjadi salah satu bentuk pembelajaran yang membentuk karakter peserta didik untuk tidak hanya didominasi oleh salah seorang peserta didik yang pandai, tetapi semua peserta didik ikut terlibat di dalamnya, yaitu peserta didik menuangkan idenya di dalam papan edukasi ketika pertanyaan diberikan oleh tutor di dalam kelas. Hasil ide yang dituangkan dalam kertas tersebut akan dipertanggungjawabkan oleh peserta didik ketika ditanyakan oleh tutor. Hal ini bertujuan untuk mengaktifkan peserta didik sehingga tidak terjadi perasaan kurang bersahabat dari setiap peserta didik akibat terbentur oleh faktor usia dan pekerjaan. Disamping itu, media pembelajaran ini diharapkan mampu membentuk karakter peserta didik menjadi pribadi yang unggul dan terampil di dalam kelas.

\section{Metode Pelaksanaan}

Pada kegaiatan pengabdian ini solusi yang ditawarkan atas dasar permasalahan prioritas yang dihadapi oleh lembaga non formal dimana solusi ini tidak hanya untuk kepentingan jangka pendek yang sifatnya sementara tetapi merupakan solusi jangka 
panjang untuk mempertahankan kualitas lembaha pendidikan non formal dengan meningkatnya persaingan di luar. Solusi penggunanaan papan edukasi berbasis karakter dapat meningkatkan motivasi belajar peserta didik, tidak hanya sebatas pada masa pandemic Covid-19 tetapi untuk keberlangsungan life time pendidikan jauh ke depannya. Adapun implementasi media pembelajaran ini penerapannya dilakukan pada dua bidang yang menjadi permasalahan prioritas mitra yaitu:

a) Aspek pembelajaran, yaitu proses pembelajaran bahasa Inggris dengan memanfaatkan media papan edukasi guna meningkatkan kualitas pembelajaran di dalam kelas. Disamping itu, proses pembelajaran dapat meningkatkan motivasi belajar peserta didik dalam lingkup pendidikan kesetaraan.

b) Aspek karakter, yakni menuntun peserta didik untuk aktif di dalam kelas tanpa membebani usia sebagai prioritas faktor yang mengahalangi proses pembelajaran. Disamping itu, hal ini sebagai solusi alternatif bagi tutor untuk memanfaatkan papan edukasi dalam belajar jaga jarak ketika di dalam kelas. Dengan hanya sebatas menliskan respon peserta didik melalui papan edukasi, dapat mengaktifkan peserta didik dan melahirkan ide-ide yang brilian terhadap materi yang disampaikan tutor.

Metode yang digunakan dalam pemberdayaan masyarakat untuk mendukung kelancaran pelaksanaan pembelajaran adalah peningkatan motivasi belajar peserta didik. Selain itu perlu diadakan demosntrasi pembelajaran melalui pemanfaatan papan edukasi. Setelah kegiatan demonstrasi proses pembelajaran dapat dilanjutkan oleh tutor untuk mengajar dengan menggunakan papan edukasi di dalam kelas.

\section{Hasil dan Pembahasan}

\section{Ruang Lingkup Pendampingan Gerakan Literasi}

Pendampingan ini dibatasi pada ruang lingkup inovasi pembelajaran menggunakan papan edukasi dalam mengembangkan karakter peserta didik paket $C$ secara individu. Bentuk pengembangan karakter peserta didik Paket $C$ tersebut mengarah pada nilai kejujuran, percaya diri, tanggungjawab, dan toleran. Secara khusus, pendampingan ini mengacu pada pembelajaran Paket $C$ kelas I atau setara dengan SMA kelas X (sepuluh) untuk standar pendidikan formal. Penulis mengarahkan penggunaan media pembelajaran "Papan Edukasi" pada mata pelajaran Bahasa Inggris, yang mengacu pada silabus dengan Standar Kompetensi (SK) (8) dan Kompetensi Dasar (KD) (8.2), yang secara khusus mengangkat materi pembelajaran yaitu Descriptive Text, dengan indikator pembelajaran yaitu mengungkapkan makna dalam teks monolog sederhana dengan menggunakan ragam bahasa lisan secara akurat, lancar dan berterima dalam konteks kehidupan sehari-hari dalam teks berbentuk descriptive text.

Topik yang dibicarakan dalam karya nyata ini mengacu pada Animal Descriptive Text. Dalam kegiatan pembelajarannya, media inovasi pembelajaran "Papan Edukasi" diarahkan pada strategi pembelajaran guessing words berupa "Who Am I?", yang bertujuan untuk membangun karakter peserta didik untuk bersikap jujur, percaya diri, tanggungjawab, dan toleran. Oleh karena itu, keaktifan peserta didik di dalam kelas tidak hanya didominasi oleh peserta didik yang pandai saja, melainkan semua peserta didik bisa aktif. 


\section{Inovasi Pembelajaran}

Mengarah pada visi PKBM Nurain, Kabupaten Bone Bolango yaitu "terciptanya warga belajar yang cerdas, religi, jujur, bertanggungjawab, percaya diri, toleran, dan kreatif sehingga sanggup dan mampu mewujudkan peningkatan taraf hidup keluarga dan komunitas" menjadi langkah dasar untuk menerapkan media inovasi pembelajaran "Papan Edukasi" guna mengembangkan karakter peserta didik Paket C di PKBM Nurain. Pengembangan karakter tersebut mengacu pada empat karakter yaitu kejujuran, percaya diri, tanggungjawab, dan toleransi. Keempat karakter ini dijadikan sebagai asset bagi peserta didik untuk berbudi pekerti yang baik disamping pengembangan karakter yang lainnya.

\section{Deskripsi “Papan Edukasi”}

Deskripsi "Papan Edukasi" sebagai media pembelajaran dalam pembentukan karakter peserta didik Paket $C$ meliputi dua bagian, yaitu pembuatan papan edukasi, dan bentuk capaian pengembangan karakter peserta didik.

\section{Pembuatan Papan Edukasi}

Papan Edukasi merupakan salah satu media pembelajaran yang terbuat dari bahan dasar limbah kantor atau sebagai hasil recycle (daur ulang) yaitu file plastik bekas, kertas HVS bekas, dan kardus.

Dalam prosesnya, tahapan pembuatan papan edukasi meliputi langkah-langkah antara lain: 1) Mengumpulkan limbah kantor berupa kardus, kertas HVS bekas, dan file plastik bekas; 2) Melengkapi bahan dasar papan edukasi dengan peralatan seperti lak ban, gunting, perekat; 3) Gunting file berkas plastik dan kardus seukuran kertas HVS; 4) Rekatkan kertas HVS bekas di atas kardus yang telah dipotong; 5) File berkas yang telah digunting kemudian direkatkan di atas kertas HVS; 6) File yang telah direkatkan tersebut direkatkan dengan lak ban pada setiap sisi atas dan bawah; 7) Hasil karya pembuatan papan edukasi sebagai media sudah siap digunakan.

\section{Bentuk Pengembangan Karakter Peserta Didik Paket C}

a) Kejujuran

Menilai kejujuran di dalam kelas Paket C tidak dapat dilakukan melalui analisis statistik jawaban benar dan salah dalam sebuah ujian. Bahkan, dalam proses penilaiannya, kejujuran tidak dapat dinilai melalui indeks integritas lembaga yang sifatnya terbatas. Oleh karena itu, nilai pengembangan kejujuran yang diterapkan kepada peserta didik melalui media "Papan Edukasi" ditentukan melalui kemampuan peserta didik dalam menulis jawaban berdasarkan pertanyaan yang diberikan oleh tutor, sehingga ketika ditanya oleh tutor atas jawaban mereka, peserta didik mampu mempertahankan jawabannya sesuai tingkat pemahamannya terhadap materi.

b) Percaya Diri

Melalui penggunaan media pembelajaran "Papan Edukasi", nilai percaya diri peserta didik Paket $C$ dapat diukur dari keaktifan mereka di dalam kelas. Ketika tutor memberikan pertanyaan kepada peserta didik, mereka kemudian menuliskan jawaban mereka satu per satu pada papan edukasi. Kemudian, masing-masing peserta didik mengangkat jawabannya ke atas. Dengan mengangkat papan edukasi ke atas pada 
akhirnya dapat merepresentasikan penilaian terhadap keberanian mereka di dalam kelas. Apalagi, keberanian mereka dalam mempertahankan jawaban yang mereka tulis itu yang mampu menunjukkan nilai kepercayaan diri mereka.

c) Tanggungjawab

Terkait dengan nilai percaya diri di atas, nilai tanggungjawab peserta didik Paket C dapat terlihat melalui kemampuan peserta didik dalam mempertahankan jawaban yang mereka tulis ketika tutor menanyakan alasan atas jawaban mereka. Dengan cara ini, peserta didik dapat terbiasa bertanggungjawab terhadap apa yang mereka pahami dan kuasai.

\section{d) Toleransi}

Pembiasaan nilai toleransi pada diri peserta didik Paket $C$ di dalam kelas nampak terlihat melalui pengendalian emosi peserta didik dalam menjawab pertanyaan tutor. Biasanya, ketika tutor memberikan pertanyaan kepada peserta didik Paket C, peserta didik yang tahu jawabannya secara spontan menjawab pertanyaan tersebut. Sehingga, peserta didik yang pemalu atau pendiam didominasi oleh peserta didik yang aktif, dan akhirnya mereka tidak memiliki kesempatan untuk menjawab. Oleh karena itu, melalui media inovasi pembelajaran "Papan Edukasi", keaktifan peserta didik tidak didominasi oleh peserta didik yang pandai, dan bertoleransi untuk memberikan kesempatan kepada yang ditunjuk oleh tutor untuk menjawab.

\section{Prosedur Karya Inovasi Pembelajaran}

Merespons sejumlah kelemahan dalam pelaksanaan pendidikan karakter, telah diupayakan inovasi pendidikan karakter. Salah satu inovasi tersebut diterapkan melalui media pembelajaran "Papan Edukasi", yang meliputi tiga tahap, yaitu tahap perencanaan, pelaksanaan, dan evaluasi. Ketiga tahapan tersebut dapat diuraikan berikut ini:

\section{Tahap Pra Persiapan}

Mengidentifikasi karakteristik peserta didik yang ada di PKBM Nurain sebagai langkah awal untuk mengenal diri perseorangan melalui tahap perkenalan. Dalam tahap perkenalan tersebut, tutor memberikan selembaran angket untuk peserta didik terkait dengan kelengkapan data diri peserta didik. Identifikasi karakteristik peserta didik di dalam kelas biasanya dilakukan dalam dua tahapan berikut:

\section{Tahap Kelengkapan Data}

Pada tahap ini, peserta didik mengisi form biodata untuk mendata nama lengkap, tempat tanggal lahir, alamat, nomor telepon, serta beberapa hal yang terkait dengan kepribadian diri, dalam hal ini, mengungkapkan karakteristik peserta didik secara umum. $\mathrm{Hal}$ ini bertujuan untuk mengetahui informasi personal peserta didik secara jelas, khususnya terkait dengan siapa peserta didik tersebut serta sebagai gambaran tentang diri pribadi peserta didik.

Disamping pengisian form biodata diri, untuk mengenal lebih jauh terhadap peserta didik, keramahtamahan (hospitality) yang ditonjolkan kepada peserta didik dari tutor PKBM Nurain menjadi produk pengenalan profil karakter pihak PKBM kepada peserta didik. 


\section{Tahap Persiapan}

a.) Menyediakan papan edukasi sesuai jumlah peserta didik yang berada di dalam kelas. Papan edukasi yang dimaksud adalah kartu yang dapat terbuat dari limbah kantor bekas tadi.

b.) Memilih Kompetensi Dasar yang sesuai dengan media pembelajaran "Papan Edukasi" untuk mengembangkan karakter peserta didik dalam materi yang diajarkan. Dalam karya nyata ini, penulis mengajar dengan media pembelajaran "Papan Edukasi" ini dalam topik "Descriptive Text". Materi pembelajaran ini mengacu pada standar isi untuk Program Paket A, Paket B, dan Paket $C$ yang diatur dalam Permendiknas No. 14 Tahun 2007, dan mengacu pada standar kelulusan yang diatur dalam Permendikbud Nomor 54 Tahun 2013.

c.) Menyiapkan perangkat pembelajaran, meliputi: silabus, RPP (Rencana Pengajar Pembelajaran) (lihat lampiran 2), dan media pembelajaran termasuk Papan edukasi. Pada karya nyata ini, penulis mencontohkan salah satu silabus dan RPP yang digunakan dalam kegiatan pembelajaran Descriptive Text.

\section{Tahap Pelaksanaan}

Berikut karya nyata yang dilakukan penulis dengan inovasi media pembelajaran "Papan Edukasi" untuk mengembangkan karakter peserta didik aktif di dalam kelas.

a) Menjelaskan materi yang diajarkan

Disesuaikan dengan KD dalam pembelajaran bahasa inggris di kelas Paket $C$ (lihat lampiran 2), penulis mengajarkan materi "Descriptive Text" khususnya tentang Describing Animal

Dalam menjelaskan materi tentang describing animal tersebut, tutor menggunakan slide untuk memudahkan dalam menjelaskan serta memudahkan dalam memahami materi.

b) Memperkenalkan Bentuk dan Prosedur Penggunaan Media "Kabar Jupaggola"

Setelah tutor menjelaskan materi kepada peserta didik, maka tutor memperkenalkan penggunaan media "Papan Edukasi" kepada peserta didik sekaligus prosedur dalam penggunaan media tersebut.

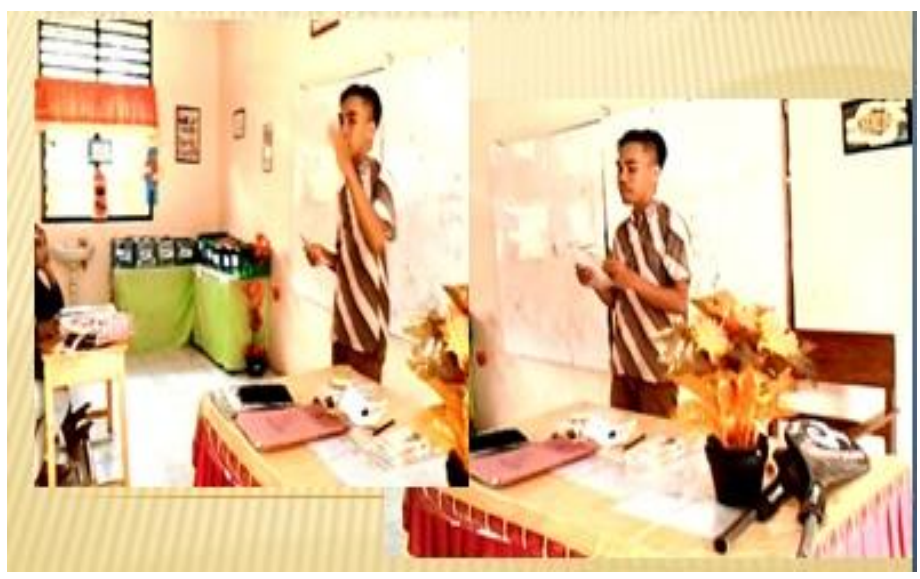

Gambar 1. Penjelasan Prosedur Penggunaan "Papan Edukasi" 


\section{c) Penggunaan Media "Papan Edukasi"}

Dalam penerapannya, penggunaan media "Papan Edukasi" ini dapat digunakan dalam kelompok atau individu. Media pembelajaran ini digunakan oleh tutor untuk menghidupkan suasana di dalam kelas melalui sebuah permainan sederhana yang menuntut keaktifan peserta didik baik dalam kelompok maupun secara individu.

\section{Penggunaan Media secara Individu}

Penggunaan media "Papan Edukasi" secara individu bertujuan untuk melatih keaktifan peserta didik di dalam kelas, sehingga ketika menjawab pertanyaan dari tutor tidak hanya didominasi oleh peserta didik yang pandai, tetapi semua peserta didik juga ikut terlibat berpartisipasi dalam kelas. Ketika tutor menyampaikan pertanyaannya, peserta didik menuliskan idenya di dalam kertas tersebut, kemudian tutor meminta salah seorang peserta didik untuk mengutarakan jawabannya serta mampu mempertanggungjawabkan alasannya kenapa menjawab seperti itu. Hal ini mampu mengaktifkan semua peserta didik di dalam kelas tanpa harus berebutan dalam menjawab pertanyaan yang diberikan oleh tutor sehingga orang yang memiliki sifat pemalu dan penakut ikut andil berbicara dan aktif berpartisipasi di dalam kelas.
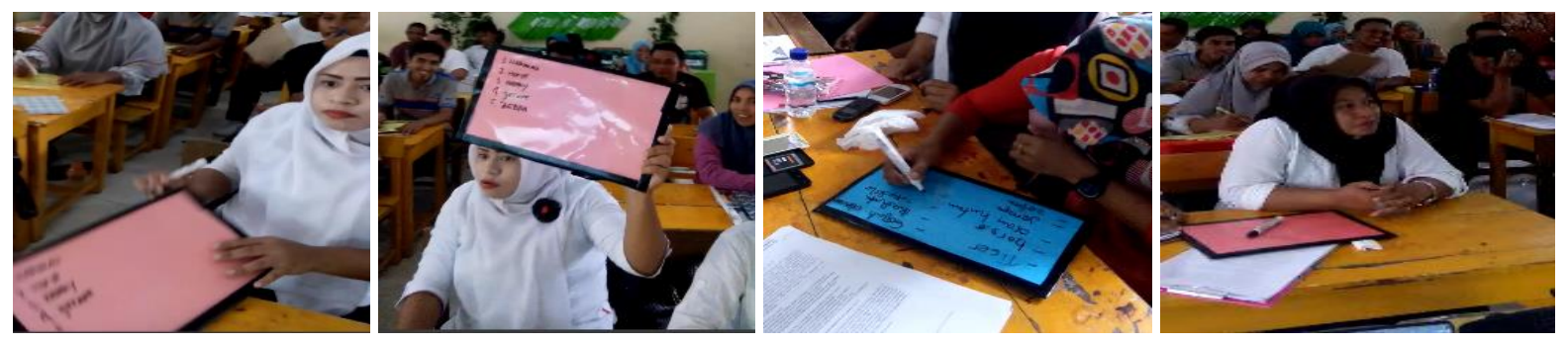

Gambar 2. Kabar Secara Individu

Melalui penerapan media pembelajaran "Papan Edukasi" ini, nilai-nilai karakter peserta didik seperti kejujuran dalam menjawab pertanyaan, kepercayaan diri melalui keberanian, tanggungjawab dalam mempertahankan jawaban, dan toleransi melalui pemberian kesempatan kepada orang lain dapat terbentuk dengan baik.

\section{Penggunaan Media secara Kelompok}

Tujuan penggunaan media "Papan Edukasi" dalam kelompok tidak hanya melatih peserta didik untuk aktif dalam kelompok melainkan melatih peserta didik untuk kompak dalam kelompok. Dalam hal ini peserta didik dapat menuliskan ide mereka bersama dalam papan edukasi tersebut, sehingga tampak terlihat adanya kerjasama dan penyatuan ide di antara beberapa orang dalam kelompok tersebut. Ide kolektif dalam papan edukasi tersebut perlu dipertanggungjawabkan oleh kelompok ketika ditanya alasan atas ide yang dituangkan dalam kartu tersebut. 

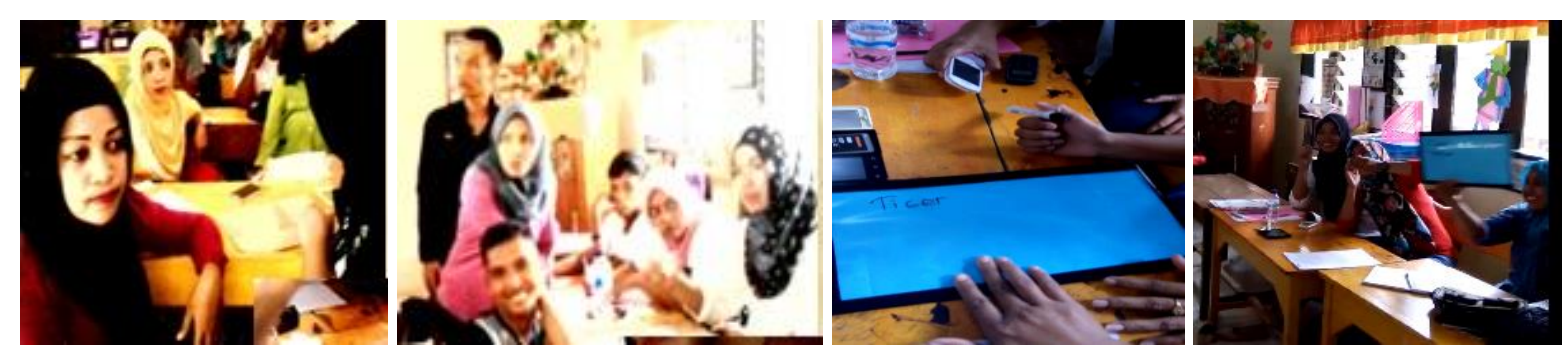

Gambar 3. Penerapan "Papan Edukasi" dalam Kelompok

\section{Tahap Evaluasi}

Dalam penilaian karakter, tutor membuat instrumen penilaian yang dilengkapi dengan rubrik penilaian untuk menghindari penilaian yang subjektif, baik dalam bentuk instrumen penilaian pengamatan (lembar pengamatan) maupun instrumen penilaian skala sikap. Dalam kaitannya, tutor meminta peserta didik untuk mengisi lembar pesan dan saran terhadap pembelajaran melalui media "Papan Edukasi", yang diperkuat dengan angket yang diberikan kepada peserta didik guna meninjau tingkat kepuasan peserta didik terhadap proses pembelajaran dengan menggunakan media "Papan Edukasi" tersebut.

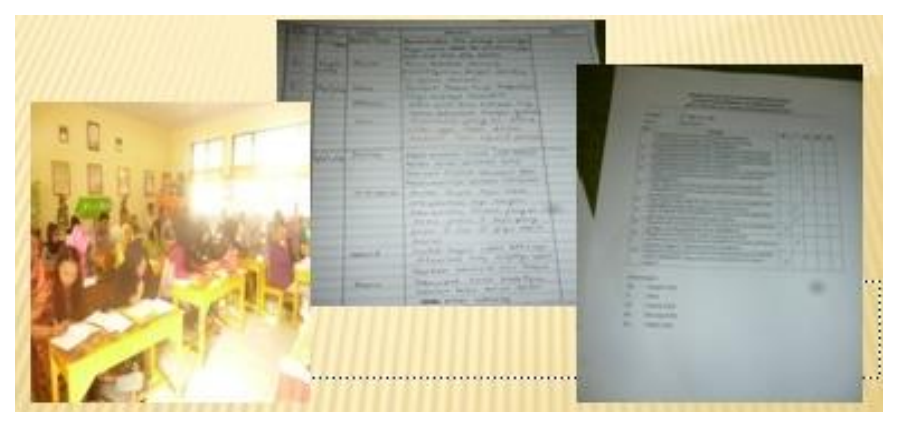

Gambar 4. Evaluasi Bentuk Saran dan Angket

Dari hasil penyebaran angket kepada peserta didik di Paket C PKBM Nurain yang berjumlah 75 orang, tutor memperoleh hasil perhitungan persentase berikut ini:

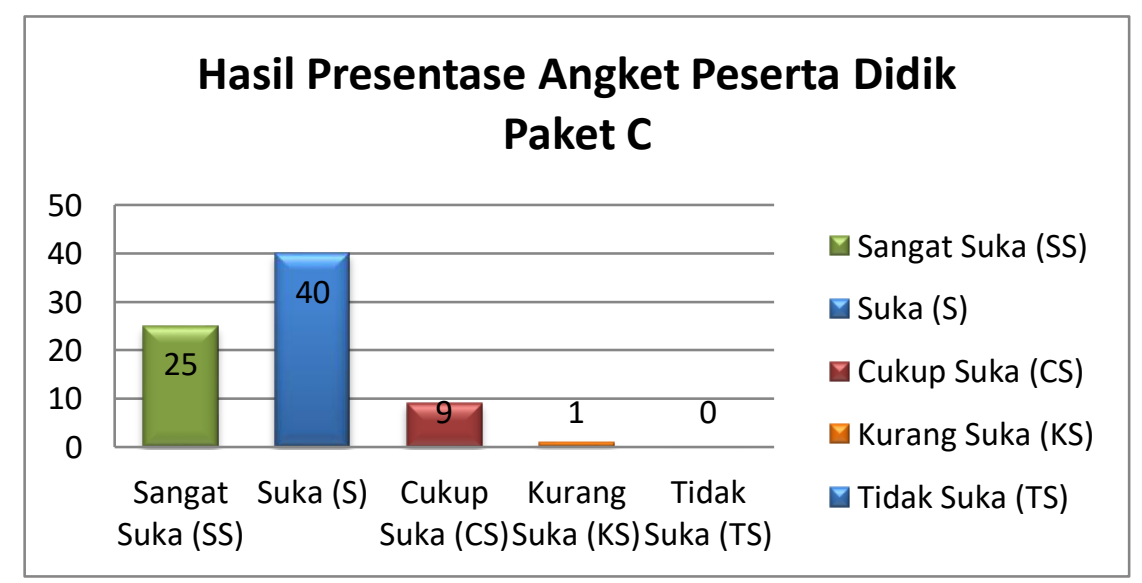

Grafik 1. Hasil Persentase Penyebaran Angket Penilaian 
Dari hasil perhitungan persentase di atas, media pembelajaran "Papan Edukasi" dapat diterima oleh peserta didik, dan sebagian besar peserta didik senang dengan pembelajaran yang menuntut keaktifan mereka di dalam kelas. Hasil perhitungan yang diperoleh dari penyebaran angket tersebut sekitar $65 \%$ dari jumlah peserta didik senang dengan media pembelajaran "Papan Edukasi" di dalam kelas. Dengan demikian, media pembelajaran "Papan Edukasi" ini mampu memancing keaktifan peserta didik di dalam kelas, dan mampu membentuk karakter peserta didik Paket $C$, khususnya pembentukan karakter kejujuran, percaya diri, tanggungjawab, dan toleran.

\section{Kesimpulan}

Bertitik tolak pada pembahasan di atas, karya nyata ini dapat disimpulkan bahwa prosedur penggunaan media pembelajaran "Papan Edukasi" ini diaplikasikan meliputi tiga tahapan yaitu perencanaan, pelaksanaan, dan evaluasi. Dalam tahap perencanaan, terlebih dahulu penulis mempersiapkan perangkat pembelajaran terkait dengan pengembangan karakter peserta didik Paket $C$. Pada tahap pelaksanaan, pembelajaran diarahkan pada pemanfaatan media pembelajaran sebagai bentuk inovasi untuk mengembangkan karakter peserta didik. Selanjutnya, pada tahap evaluasi, untuk meninjau penerapan inovasi pembelajaran dapat diterima oleh peserta didik, maka penulis menyediakan angket dan lembaran kesan dan pesan terhadap pembelajaran bahasa Inggris dengan menggunakan media "Papan Edukasi."

Hasil implementasi media pembelajaran "Papan Edukasi" ternyata mendapat respon positif bagi setiap pihak yang terlibat, antara lain: minat belajar, karakter, serta nilai peserta didik meningkat. Dampak yang dapat dirasakan berimbas pada beberapa pihak, yaitu bagi peserta didik, bagi tutor Program Kesetaraan Paket $C$, dan bagi kemitraan kelembagaan.

Keunggulan dari inovasi media pembelajaran "Papan Edukasi" ini dapat ditinjau dari beberapa aspek, antara lain: 1) tujuan pembelajaran tercapai dengan baik; 2) biaya yang digunakan dalam pembuatan media pembelajaran relatif murah, praktis, dan terjangkau; 3) melalui media pembelajaran ini, waktu yang digunakan lebih praktis; 4) media pembelajaran ini memberikan aksesibiliti bagi peserta didik untuk mengembagkan karakter mereka di dalam kelas. Sementara itu, kelemahan dari inovasi pembelajaran ini dapat ditinjau dari dua aspek yaitu pengembangan dalam materi pembelajaran dan dalam konteks penanaman, pembiasaan, pembentukan, dan pengembangan karakter membutuhkan waktu yang lama.

\section{Ucapan Terimakasih}

Ucapan terima kasih disampaikan kepadan PKBM Nurain, Kecamatan Tapa, Kabupaten Bone Bolango yang telah bersedia menjadi tempat pelaksanaan pengabdian yang dilakukan oleh penulis sehingga bisa menghasilkan karya nyata yang dapat digunakan tidak hanya bagi penulis tetapi juga bagi setiap lembaga pendidikan kesetaraan. 


\section{Referensi}

Diggs, C. R., \& Akos, P. (2016). The promise of character education in middle school: A meta-analysis. Middle Grades Review, 2(2), 1-19.

Nurhasanah, N., \& Nida, Q. 2016. Character Building of Students by Guidance and Counseling Teachers Through Guidance and Counseling Services. Jurnal Ilmiah Peuradeun, 12.

Prameswara, A., \& Siswanto, R. A. (2016). Perancangan Board Game Edukasi Sebagai Media Pembelajaran Untuk Menumbuhkan Minat Baca Anak Jalanan Di Bekasi. e-Proceeding of Art \& Design, 3(3), 423-30.

Simbolon, A., Parlindungan, S., \& Sibuea, E. R. (2018). Improving the students' speaking skills through board games to the tenth grade students of SMA Negeri 2 Padangsidimpuan. Jurnal ESTUPRO, 3(3).

Widyahening, E. T., \& Wardhani, N. E. (2016). Literary Works and Character Education. International Journal of Language and Literature, 4(1), 176-180. 